\title{
Concern in committee
}

\section{London}

AN all-party House of Commons committee has announced that it is "very concerned over serious financial difficulties facing many universities". The statement came in the Public Accounts Committee's report on financial problems at universities, which was prompted by the financial crisis at University College, Cardiff, during the 1980 s.

Cardiff's problems arose from the failure to reduce staff numbers in the face of a smaller grant allocation in the early 1980s. Despite pressure from the Department of Education and Science (DES) and the old University Grants Committee (UGC), the college's deficit worsened until the DES withheld its grant in February 1987 . This was restored a month later, but only after a new team of financial managers had been appointed and Bill Bevan, the college's principal, had stepped down. University College, Cardiff, has now been merged with the University of Wales Institute of Science and Technology.

As expected, the committee's report condemns the college's financial management up to 1987 . "There was no credible and co-ordinated financial and academic planning", the report concludes.

The report also vindicates the DES's "unprecedented action" of overriding university autonomy to "restore financial discipline" to the college. But the UGC is criticized for failing to take decisive action before the college's problems had become deeply entrenched, and for not reporting the situation to parliament earlier.

The establishment of the Universities
Funding Council (UFC, which replaced the UGC in April 1989), is welcomed by the Public Accounts Committee, which expects the UFC to take a more interventionist role than the UGC to ensure economy and public accountability of university funding. The UFC is currently monitoring the final stages of universities' restructuring programmes, which have involved staff cuts, mostly through early retirement or voluntary redundancy. Sir Peter Swinnerton-Dyer, chief executive of the UFC, was due to appear before the Public Accounts Committee this week to give evidence on the accidental misuse of some funds intended for restructuring by some universities.

Despite restructuring, many universities still face financial problems. The UGC reported in 1987 that universities' costs were expected to rise faster than their incomes. The University of London, which predicts an accumulated deficit of $£ 46$ million by $1992-93$, on an annual budget of over $£ 600$ million, is the UFC's major concern. Of London's 15 major colleges, only the London School of Economics is not in debt. Lord Flowers, London's vice-chancellor, has discussed the problem with the UFC, which will debate the issue at its next meeting in March. The UFC stresses that it is not accusing London of financial mismanagement; the university's problems stem mainly from the costs of operating in an expensive capital city. London's management believes the university is underfunded to the tune of about $£ 10$ million per year, but the UFC has not yet accepted this figure.

Peter Aldhous

\section{BSE compensation}

\section{London}

IN a policy reversal, the UK agriculture minister John Gummer announced last week that British farmers will receive full compensation for the destruction of cows infected with bovine spongiform encephalopathy (BSE), rather than half the market price. The increase should remove any remaining temptation for farmers to sell infected cows for human consumption.

Veterinary and health groups have been campaigning for full compensation, but the Ministry of Agriculture, Fisheries and Food says that the decision is not the result of lobbying, or of concern for public health. A ministry spokesman said that the change reflected government recognition of farmers' loss of a valuable export market (the European Commission decided recently to ban the export from the United Kingdom to other Community countries of all live cattle older than six months), and the increasing number of herds in which several BSE cases were being found. P. A.

\section{Lasker prize hiatus}

\section{Washington}

IN a surprise announcement, the Albert and Mary Lasker Foundation said last week that it would suspend its respected medical research awards for the year to rethink their future.

"We are reviewing our whole programme", says Alice Fordyce, executive vicepresident of the foundation and director of the medical awards. She stressed that the move was not based on financial considerations, but was rather because, after 44 years, it had become necessary to reappraise the impact of the award. "We need to get feedback from the community. . . . Were we making a difference? Should we be doing things some other way?" she asks.

The hiatus is the first since 1961 when the awards were put off for one year to accommodate bureaucratic changes. Although lack of money is said not to be a factor, the foundation's assets are down from $\$ 4.5$ million in 1980 to $\$ 2.4$ million.

Each winner normally receives a $\$ 15,000$ honorarium at a ceremony held each September. Since the awards were established in 1944, 46 winners have gone on to receive Nobel Prizes.

\section{ESA names new DG}

\section{London}

JEAN-MARIE Luton, director general of the French National Centre for Space Studies (CNES), will replace Reimar Lüst as director general of the European Space Agency (ESA) for four years from 1 October this year. Luton has a background in geophysics research, and is currently a French delegate to the council of ESA. From 1984 to 1987, he chaired ESA's administrative and finance committee.

Wellcome has also agreed to provide NATURE - VOL $344 \cdot 1 \mathrm{MARCH} 1990$ 